УДК 8

DOI $10.21661 / \mathrm{r}-115503$

\title{
О.В. Дедюхина
}

\section{ОБРАЗ ДЕМОНИЧЕСКОЙ ЖЕНЩИНЫ В ПОВЕСТЯХ И.С. ТУРГЕНЕВА}

Аннотация: в статье предпринимается попытка уточнения типологии женских образов в повестях Тургенева, выявляется, что кроме образа «тургеневской девушки», характерного, прежде всего, для романов писателя, выделяется образ «демонической женщины», наиболее частотный в повестях. По мнению автора, образ «демонической женщины» соотносится с философскими взглядами писателя на природу, с его конщепџией любви, данный образ обнаруживается в повестях, изображающих любовь как роковую власть, подчиняющую волю. Характерными чертами героинь, принадлежащих к данному типу, становятся властность и сила характера. Автор считает, что образ «демонической женщиныл» создается Тургеневым как в реалистической манере, так и с привлечением ирреальных мотивов.

Ключевые слова: поэтика, типология образов, женские образы, тургеневская девушка, конщепџия любви, философия природь, ирреальное.

\section{O.V. Dedyukhina}

\section{THE CHARACTER OF DEMONICAL WOMAN IN THE TURGENEV'S NOVELS}

Abstract: the article describes the women' characters in Turgenev's novels, discovers that there is the character of "demonical woman", which is used in the novels often enough, besides the character of "Turgenev's young lady", representing his novels. According to the author the character of "demonical woman" is associated with author's philosophic point of view about nature and with his love concept, this character is found in the novels, representing love as a fateful power which brings under 
control freedom. These women' characteristic features are power and strong personality. The author considers that the character of "demonical woman" is created by Turgenev in real and unreal manners.

Keywords: poetics, characters" type, women'type, Turgenev's young lady, love concept, nature philosophy, unreal.

«Любовь, поклонение женщине наполнили всю его жизнь, сопровождали его до могилы», - писал о Тургеневе Б.К. Зайцев [1, с. 29]. Сам писатель, по воспоминаниям Э. Гонкура, утверждал: «Нет ни книги, ни чего бы то ни было на свете, что бы могло заменить мне женщину... По-моему, одна только любовь дает тот полный расцвет жизни, которого ничто не дает» [4, с. 240]. Когда Тургенева спросили о самой счастливой минуте его жизни, он ответил: «Разумеется, самая счастливая минута жизни связана с женской любовью» [4, с. 353]. А. Шопенгауэр в трактате «Метафизика половой любви» подчеркивает то, что мировой философской мыслью вопрос о любви достаточно не разработан, тогда как для поэтов любовь - постоянная тема творчества. В таинство любви, в непостижимую силу власти ее над душами людей стремится проникнуть и Тургенев, изображая на страницах своих произведений любовь в совершенно различных ее проявлениях.

Взгляд Тургенева на сущность любви определяется как его философией природы, так и личным опытом писателя. Как известно, одной из центральных философских идей, разрабатываемых Тургеневым на протяжении всей его творческой жизни, была мысль о человеческом ничтожестве, во многом обусловленная увлечением писателя философией Паскаля. Во многих произведениях Тургенева звучит мысль о краткости, мимолетности человеческой жизни, о беззащитности человека перед «равнодушной» Природой и невозможности для него постичь тайны мироздания, проникнуть в Неведомое. Природной, а значит, стихийной, силой в представлении писателя является любовь. В понимании Тургенева любовь - чувство прекрасное, преобразующее мир и человека, и в то же 
время трагическое, несущее разрушение и гибель, это стихийная, роковая сила, овладевающая человеком помимо его воли и превращающая его в раба.

Любовь прихотливо распоряжается человеческой судьбой, ее власть писатель испытал на собственном опыте. Главной женщиной в его жизни стала Полина Виардо, в течение тридцати восьми лет, с 1845 года до самой смерти в 1883 году, Тургенев был фактически членом семьи Виардо, живя в их доме или снимая жилье неподалеку, провел всю жизнь на краешке чужого семейного гнезда. Я. Полонский вспоминает о том, как Тургенев признался ему, что Виардо имеет над ним «какое-то особое влияние, держит его у своих ног какими-то будто чарами, словно колдовством, и что он, когда ее видит, физически не может не подчиниться ей, что это выше его сил и он находится в ее присутствии как бы под сильнейшим гипнозом» [4, с. 142]. Некрасову, навестившему Тургенева за границей, писатель говорил, что даже спустя пятнадцать лет со дня знакомства с Полиной Виардо он готов по ее приказанию «плясать на крыше, нагишом, выкрашенный желтой краской!» [2, с. 381].

М.А. Петровский подчеркивает иррациональность тургеневской любви: «Как таинственное, со всеми своими синонимами, становится у Тургенева часто синонимом зловещего и странного, так и любовь, в своей стихийности, многократно изображается им, как сила недобрая <.. >, разрушительная, сулящая беду и возбуждающая чувство страха» [5, с. 85].

Тургенев ввел в литературу новый женский образ - поэтический образ «тургеневской девушки» - Натальи Ласунской, Лизы Калитиной, Елены Стаховой и др. «Тургеневская девушка» - девушка из дворянской усадьбы, чистая, возвышенная, одухотворенная, обладающая сильным характером, способная на самопожертвование. Писатель изображает наиболее важный период в женской судьбе, когда в ожидании избранника расцветает ее душа, пробуждаются все ее потенциальные возможности. «Бесплотными и бескровными призраками» называет Д.С. Мережковский образы тургеневских девушек и женщин, стремясь подчеркнуть их идеальность [3, с. 539]. Однако образом «тургеневской девушки»не 
может быть исчерпана типология женских образов в творчестве писателя. В произведениях Тургенева, в которых первостепенное значение приобретает тема любви-власти, как правило, присутствует иной женский тип - образ «демонической женщины».

Образ «демонической женщины» характерен, прежде всего, для повестей писателя, он имеет различные модификации. В повести «Петушков», возможно, сам того не желая, Тургенев предсказывает свою собственную судьбу, а именно то, что он, как и его герой, офицер Петушков, будет в любовном плену у одной женщины и проведет свою жизнь на «краешке чужого семейного гнезда». Петушков погибает от любви, считая власть Василисы над собой колдовской и не умея освободиться из-под ее плена. Герой чувствует, что потерял связь с реальностью. «Да что это я словно во сне хожу? - думал он про себя, - с ума я сошел что ли?» [6, т. 5, с. 167]. Абсолютно потеряв не только волю, но и собственное достоинство, Петушков поселяется в чуланчике при булочной, лишь бы быть рядом со своей возлюбленной.

Чтобы показать всевластие любви, Тургенев делает героев повести людьми ничем не примечательными, заурядными. Рабская любовь Петушкова никак не мотивирована личностными качествами Василисы. Она неграмотна, живет бездумно и неинтересно, ее жизнь не освещена лучом сознания. Во внешнем облике Василисы автор подчеркивает простоту, обыкновенность и чувственную привлекательность. «Лицо она имела полное, круглое, щеки румяные, глаза карие, небольшие, нос несколько вздернутый, русые волосы и великолепные плечи» [6, т. 5, с. 160]. Когда Тургенев описывает, как Петушков впервые увидел Василису, он использует такую деталь, как «булка», которая способствует прозаизации образа героини. Однако Василиса, несмотря на свою заурядность, играет в судьбе поручика Петушкова роковую роль. Сама того не желая, она становится для него «демонической женщиной», таинственным чарам которой он противостоять не может. 
К типу «демонической женщины» может быть отнесен и образ Аграфены Ивановны из повести «Бригадир». В произведении появляется мотив воссоединения с возлюбленной через смерть, который найдет дальнейшее развитие в повести «После смерти». Главный герой повести, бригадир Гуськов, - старичок, доживающий восьмой десяток, потерявший состояние, имеющий «из милости» угол, уже слабеющий умом. Уже далекий от реальности, мало что понимающий Гуськов оживляется, когда речь заходит о дорогом для него существе. В образе престарелого бригадира Тургенев создает героя, несущего в себе какую-то загадку, тайну. Тайна любви становится в данной повести ключевой.

В образе Аграфены Ивановны перед нами предстает сильная, страстная натура, самовластная помещица, женщина надменная и вспыльчивая, привыкшая к поклонению и стремящаяся повелевать. В облике героини подчеркивается волевое начало. Лицо ее, «недоброе», как позже заметит рассказчик [6, т. 10, с. 59], с узким носом с горбинкой, правильными, но узкими губами, прямыми густыми сдвинутыми бровями «не глядело на зрителя, как бы отворачивалось от него и не улыбалось» [6, т. 10, с. 59]. Аграфена Ивановна играет роковую роль в судьбе бригадира. Он жертвует для нее всем: и своей честью, и своим состоянием, ничего не получая взамен. Бригадир был в совершенной ее власти, как пишет он статсткой советнице Ломовой: «...и потому не мог уже управлять ни самим собою, ни моей собственностью - а распоряжалась она по своей воле как мною, так и моим состоянием!» [6, т. 10, с. 68]. Признание Гуськова в том, что он часто видит во сне свою возлюбленную, с одной стороны, выступает как характерологическая деталь, указывающая на ту власть, которую имела Аграфена Ивановна над душой бригадира и при жизни, и после смерти. С другой стороны, сон носит концептуальный характер, призван выразить основную идею повести: любовь сильнее смерти, торжествует над нею.

В повести «Вешние воды», организуя систему образов, Тургенев противопоставляет двух героинь: Джемму и Марью Николаевну Полозову. Образ Джеммы может быть отнесен к типу «тургеневской девушки», автор акцентирует 
в Джемме такие черты, как благородство, возвышенность, идеальность. Полозову же сам Тургенев в одном из писем называет «женщиной-дьяволом», подчеркнув, что она соблазнила его так же, «как она соблазнила простофилю Санина» [6, т. 9, с. 418]. Создавая образ Полозовой, автор указывает на искусительное, хищное начало в ней, прибегает к зоологическим сравнениям с хищными животными: кошкой, змеей, ястребом, который когтит свою жертву. Обрисовывая портрет героини, автор акцентирует внимание на притягательности ее «цветущего женского тела»: у нее «прелестнейшая шея, удивительные плечи», «удивительный стан», ее губы - «алые длинные вкусные губы» [6, т. 11, с. 110]. Важную роль при создании образа Марьи Николаевны играют символические образы: железное кольцо, которое она давала своим поклонникам, выступает символом их рабского подчинения ей, хлыстик с коралловой ручкой - символом ее женской власти. Говоря о власти Полозовой над Саниным, Тургенев подчеркивает ее сильный, волевой характер, во взгляде ее «проступало что-то недобpoе... что-то угрожающее» [6, т. 11, с. 115]. Стремление к собственной независимости и свободе, а также желание власти над другими отличают Полозову.

В повести Тургенев изображает два типа любви: любовь идеальную, романтическую, одухотворенную, преображающую человека, делающую его лучше, сильнее, которая соотносится с образом Джеммы; и любовь чувственную, роковую страсть, разрушающую личность, превращающую в раба, соотносящуюся с образом Полозовой.

Несколько иной образ «демонической женщины» обнаруживается в повести «Призраки». В произведении отразился пессимистический взгляд Тургенева на общество и историю человечества, писатель ведет речь об иллюзорности бытия, история, в его понимании, - многовековой сон. Повесть «Призраки» автор назвал «фантазией», ее сюжет строится как путешествие героев (рассказчика и Эллис) сквозь пространство и время то ли во сне, то ли наяву.

В «Призраках» отсутствует социальная детерминированность героев и событий. Образы главных героев произведения отличаются какой-то аморфностью, неопределенностью, неясностью. Единственное, что известно о герое, это 
то, что он, по-видимому, проявляет интерес к спиритическим сеансам. Вначале относясь скептически к возможности общения с призраками, постепенно он начинает верить в реальность существования Эллис. После прикосновения к таинственному миру жизнь героя меняется: начинаются болезни, и смутное ощущение чего-то неуловимо страшного не дает покоя, вызывая мысль о ничтожестве всего сущего.

Образ Эллис столь же неопределенен: она то ли привидение, скитающаяся душа, то ли злой дух, сильфида, вампир. То, что Эллис, «белая женщина», появляется в свете луны, сквозя как туман, свидетельствует о ее принадлежности к трансцендентальному миру. У рассказчика возникает мысль, что Эллис - сатана, так как она не знает Бога. Голос Эллис - шепот или шелест, что полностью соответствует представлениям древних о голосе духов. Они полагали, что голос духа - «дух» настоящего голоса, поэтому во времена античности описывали голос духов в форме шепота или шелеста.

Многое в обрисовке Эллис указывает на то, что она вампир. Так, вначале она «как бы соткана из полупрозрачного, молочного тумана - сквозь ее лицо ... виднелась ветка...» [6, т. 9, с. 81]. У нее «мертвенно-пристальный» взгляд, внушающий страх. Совершая полет с Эллис, рассказчик чувствует на губах «какое-то странное ощущение, как бы прикосновение тонкого и мягкого жала... незлые пиявки так берутся» [6, т. 9, с. 85]. Постепенно Эллис словно наполняется жизнью, приобретает более телесный цвет, «в темных глазах дрогнули живые искры» [6, т. 9, с. 88], губы покраснели. Перед окончательным расставанием с рассказчиком и своим исчезновением она уже не призрак, а живая женщина, ее губы «теплые, влажные, с кровяным запахом» [6, т. 9, с. 108]. Эллис стремится напитаться жизнью, перейти из мира духов в земной мир, но ей это не удается, мешает Смерть. В целом образ Эллис необходим Тургеневу для воплощения мысли об иллюзорности человеческого бытия и о неизбежности смерти для каждого живого существа.

Образ героини повести Тургенева «После смерти» Клары Милич двойственен: она сочетает в себе идеальность, возвышенность, чистоту, способность на 
самопожертвование и глубокую любовь, в то же время она чрезмерно горда, обладает какой-то бесовской одержимостью в достижении своей цели. Отец называл Клару «бесенком черномазым» [6, т. 13, с. 113]. Купфер, характеризуя Клару, отмечает, что она была «тверда, как камень» [6, т. 13, с. 102]. Сестра Анна указывает на такие черты характера героини, как своеволие, вспыльчивость, самолюбие, противоречивость, великодушие. Клара «верила в судьбу и не верила в Бога» [6, т. 13, с. 112-113]. Своенравие и властность Клары, ее бескомпромиссность особенно ярко проявлялись в ее взгляде на любовь. Она иногда говорила: «Такого, как я хочу, я не встречу... а других мне не надо!» - «Ну а если встретишь?»- спрашивала Анна. «Встречу... возьму». - «А если не дастся?»«Ну, тогда ... с собой покончу. Значит не гожусь» [6, т. 13, с. 113]. Увидев в Аратове, видимо, свой идеал, Клара полюбила его, но не нашла ответа на свое чувство и поступила согласно собственным убеждениям. «Не могу жить, как хочу, так и не надо...» [6, т. 13, с. 114] - таков был ее жизненный принцип. С ранних лет Кларе было дано предчувствие будущих трагических событий, иногда во сне она видела, что с ней будет.

Купфер в разговоре с Аратовым уже после смерти Клары отмечает, что «Горда она была - как сам сатана - и неприступна!» [6, т. 13, с. 102] Мать Клары выделяет такую черту ее личности, как независимость. В своем доме Клара казалась чужой: ни мать, ни отец не понимали ее. Трагическая отгороженность героини от мира усугублялась тем, что она отворачивалась от него, убежденная в его универсальной испорченности, и была бескомпромиссна в отношении к себе и к людям.

При обрисовке образа Клары немаловажное значение имеет цветовая символика: единственный цвет, который использует автор, создавая ее портрет,черный. В портрете Клары есть черты сходства с портретом Аграфены Ивановны из «Бригадира»: у нее черные глаза, густые, почти сросшиеся брови, тонкие губы. Обе героини и силой характера, и ролью в жизни любящих их героев, и внешним обликов напоминают Полину Виардо. 
С образом Клары, как и с образами других героинь, о которых речь шла выше, связан мотив власти. Полюбив Аратова и не найдя ответа на свое чувство при жизни, она овладевает душой героя после смерти, являясь ему в снах и видениях. Финал повести может восприниматься двояко: и как победа любви над смертью, и как страшная гибель маленького, беззащитного, ничтожного человека от непостижимых разумом законов, правящих миром.

Итак, уточняя типологию женских образов в повестях Тургенева, можно отметить, что наряду с образом «тургеневской девушки», выделяется тип «демонической женщины», который появляется в произведениях, изображающих любовь как роковую страсть. Образы тургеневских героинь, относящихся к типу «демонической» женщины, можно разделить на две группы: на тех, которые созданы в реалистической манере (это Василиса из повести «Петушков», Аграфена Ивановна из «Бригадира», Полозова из «Вешних вод»), и тех, при создании которых автор использует ирреальные мотивы (это Эллис из «Призраков» и Клара Милич из повести «После смерти»).

\section{Сиисок литературы}

1. Зайцев Б.К. Собр. соч. [Текст] / Б.К. Зайцев. - М.: Русская книга, 1998. T. $5 .-540 \mathrm{c}$.

2. Из парижского архива И.С. Тургенева [Текст]. - М.: Наука, 1964. Кн. 1. -581 c.

3. Мережковский Д.С. Л. Толстой и Достоевский. Вечные спутники [Текст] / Д.С. Мережковский. - М.: Республика, 1995. - 623 с.

4. Островский А.Г. Тургенев в записях современников: Воспоминания. Письма. Дневники. [Текст] / А.Г. Островский. - М.: Аграф, 1999. - 396 с.

5. Петровский М.А. Таинственное у Тургенева // Творчество Тургенева: Сб. ст. [Текст] / М.А. Петровский. - М.: Задруга, 1920. - С. 70-97.

6. Тургенев И.С. Полн. собр. соч. и писем: [Текст] / И.С. Тургенев. - М. Л.: Наука, 1960-1968. - Т. 28. 
Дедюхина Ольга Владимировна - канд. филол. наук, доцент кафедры русской и зарубежной литературы ФГАОУ ВО «Северо-Восточный федеральный университет им. М.К. Аммосова», Россия, Якутск.

Dedyukhina Olga Vladimirovna - candidate of philological sciences, associate professor of the Department of Russian and Foreign Literature FSAEI of HE “M.K. Ammosov North-Eastern Federal University”, Russia, Yakutsk. 